\title{
Is the Human Fairness Innate or Learned Evidence from the Ultimatum Game
}

\author{
Luo Xinqing ${ }^{1, a}$, Xie Junjie ${ }^{2, b,}{ }^{,}$, Liu Jianfeng ${ }^{3, c}$
}

${ }^{1}$ Beijing International Studies University,international business school,Beijing,China

${ }^{2}$ Beijing International Studies University, international business school,Beijing,China

${ }^{3}$ Beijing International Studies University, international business school,Beijing,China

aluoxinqing@126.com, bxjjames@yeah.net, c734376362@qq.com

${ }^{*}$ Corresponding author

Keywords: Ultimatum game, Individual difference, fairness

\begin{abstract}
As one of the classical experiments in game theory, the ultimatum game plays an important role in studying the issue of human fairness and explaining whether it is inherent or acquired. Experiments show that the primates which closest to human beings are not always making a fair choice. Experiments on human children show that the sense of equity increases with age. From the perspective of social evolution, the sense of human fairness tends to be enhanced in the process of social evolution. Recently, the research focuses on neuroeconomic which proves the sense of human fairness owns its physiological basis. The review and the study of human fairness will not only help to further explore the theory of decision making, but also benefit the practice and application of the theory of fairness.
\end{abstract}

\section{人类公平感是天生的, 还是后天习得的? 一一来自最后通牒博栾实验的证据

关键词：最后通牒博弯; 个体差异; 公平感

中文摘要. 最后通牒博弯作为行为博弯的经典范式之一, 是研究人类公平感问题的重要模型。 通过最后通牒博弯实验可以帮助解释人类的公平感是与生俱来的还是后天习得的这一命题。 实验表明, 与人类最为接近的灵长类动物作出公平选择的结果并不稳健。针对人类儿童的实 验则表明，未成年儿童的公平感会随着年龄的增长而上升。从社会演化视角看，人类的公平 感在社会进化的过程中不断增强, 即工业社会人类的公平感强于非工业社会。最近的研究则 聚焦在公平感的神经经济学解释, 实验证明人类的公平感是有生理基础的。回顾和研究人类 的公平感不仅有助于进一步探究决策理论, 还有益于公平理论的实践与应用。 


\section{1. 引言}

社会公平从古至今都是人类追求的崇高社会理想。中国古语有云“有国有家者，不患寡而 患不均”, “治身莫先于孝, 治国莫先于公”, 这无不体现出公平在社会治理中的地位。公平感 决定着个体对社会的信任，个体对社会公平的感知又影响其对公共事物的合作和参与。 ${ }^{[1]}$ 最 后通牒博弯 (Ultimatum Game, UG) 是实验经济学中的一个经典模型, 通过回顾三十多年来 相关文献, 不难发现人类在生命演化和社会变迁的过程中开始具备公平感, 而与之相伴的人 类的行为也趋向于追求公平而非完全利已。

首次最后通牒博弯实验由德国经济学家Güth, Schmittberger \& Schwarze ${ }^{[2]}$ 于1982年进行, 参与人员分为提议者 (Proposer) 与响应者（Responder）。实验内容为双方分享一笔钱一 提议者给出分配方案, 响应者选择接受或者拒绝。若响应者接受, 则双方达成一致, 这笔钱 按提议者的分配方案来分享; 若响应者拒绝, 则双方都一无所有。根据“理性经济人”假设, 提议者理应分出一个特别小的份额, 而响应者也会接受, 因为接受总好过一无所有。所有的 分出额都应视为一种均衡结果。

首次实验结果发现, 提议者平均分出初始禀赋的 $40 \%$ 到 $50 \%$, 并且这一分配方案总是被 接受; 而低于 $30 \%$ 的分出额几乎都被拒绝了。这与“理性经济人”假设相违背。响应者不仅关 注自身的利益, 更拿自身利益与提议者的相比较, 尤其是当自己处于一种不公平的情形下, 会变得愤怒而产生拒绝行为。而提议者给出的这一分配方案可能受到响应者潜在拒绝行为的 影响, 或者就是由自身公平感所驱使。所以对于提议者来说, 公平分配或者分出 $40 \%$ 是收益 最大化的决策。[3]

尽管在最后通牒博弯中提议者有机会占有更多金钱, 但他们通常分给对手接近一半的金 额; 响应者虽然也能从不公平分配中获益, 但他们宁可双方收入都是零也不愿意接受不公平。 这一行为与人类的公平感产生了密切的联系。大量最后通牒博弯实验的结果表明人类具有公 平感, 并且本质地证明了并不是所有人都会在任何情况下做出让自己利益最大化的决策。 ${ }^{[4]}$

本文的结构安排如下: 第二、第三部分对灵长类动物和儿童进行了相关文献的回顾, 发 现灵长类动物虽然表现出一定的公平感, 但结果并不稳健; 而与灵长类动物最接近的人类的 儿童却随着年龄的增长提升了公平意识; 第四部分把研究目光从儿童转向成年人, 发现人类 的公平感随着社会环境的变化而改变。简而言之, 处于原始社会或农业社会的成年人的公平 感要低于处于工业社会的成年人。这一发现可以用文化、价值观和市场化程度等因素进行解 释; 第五部分结合神经经济学研究成果, 通过前人在精神疾病中进行的病例研究, 指出公平 感具有生理基础并展望其前沿应用。

\section{2. 基于灵长类动物的实验}

利他主义, 尤其是对陌生人的利他主义在进化史上是极为罕见的, 而灵长类动物中存在 着这样的利他主义。[5] 与人类体质特征和社会行为相近的灵长类动物, 特别是黑猩猩和猴子, 在进行公平问题选择的时候可以和人类形成有效的对比。

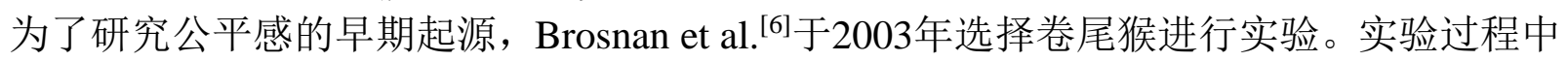
研究人员发现, 如果卷尾猴看到同类付出了与自己相同的努力而获得了更高价值的回报, 其 便拒绝参与游戏; 一旦发现同类不需要付出努力就能获得奖励时，这种抵触情绪会被放大。 这从侧面说明灵长类动物对于公平有着自己的考量。黑猩猩是灵长类动物中最能表现亲社会 行为的动物之一, 它们在日常生活中通常有巡逻领土、合作狩猎和分享食物等行为。 ${ }^{[7-8]}$ 相隔 两年, Brosnan et al. ${ }^{[9]}$ 通过实验发现黑猩猩不仅仅关注奖励本身，也会与同类的奖励进行比较， 尤其是当同类得到比自己更好的东西的时候。类似实验都证明了灵长类动物会针对结果进行 比较, 而非单纯的接受。Proctor et al. ${ }^{[10]}$ 发现黑猩猩在通过与伙伴互动进行公平分配还是利己 分配的实验中, 选择与人类大体一致。即如果提议者认识到它正在与伙伴进行合作, 那么黑 
猩猩选择公平分配。2010年, Massen et al. ${ }^{[11]}$ 针对长尾猴这一灵长类动物关于亲社会行为进行 了实验。实验表明处于高地位的长尾猴面对非亲缘群体表现出慷慨, 而处于低地位的长尾猴 则更多的保留了对食物扣留的权利。因此在灵长类动物中也存在着社会地位对公平行为的影 响。灵长类动物在实验中展现出的与人类相似的关于公平分配的行为, 证明了公平感在进化 上的可溯源性。

动物公平感的现阶段研究存在着比较大的争议。总体上看, 现有的研究还不足以证明动 物与人类具有同样的公平意识这一结论。Bräuer et al. ${ }^{[12-13]}$ 将黑猩猩在实验过程中展现出的焦 虑解释为期望——期望自己获得同样的食物——而非对不公平的厌恶。Jensen et al. ${ }^{[14]}$ 通过实 验发现黑猩猩并不会给出公平分配, 并且作为响应者黑猩猩也接受不公平分配。借此研究者 提出黑猩猩是理性最大化的并且不具备公平感。此外, Kaiser et al. ${ }^{[15]}$ 通过设计一个提议者可 以从响应者那里 “窃取” 食物的最后通牒博弯实验, 来研究灵长类动物对于公平的关注度。 研究发现提议者具有 “窃取” 行为, 并且响应者不会拒绝任何一个非零的分出额。因此研究 者提出将 “拒绝” 视作对不公平的 “惩罚” 这样的观念可算作人类独有的一种特征, 而灵长 类动物没有表现出现同样的反应。

综上, 大量针对灵长类动物的最后通牒博弯实验并没有明确证明其具有公平偏好。已经 进行的实验结论存在相互矛盾的地方。

\section{3. 基于儿童成长阶段的实验}

追溯人类的公平感, 可以先考察儿童在生长发育过程中其公平感的变化。年幼的孩子会 对苦恼的人展现同理心, 学龄前儿童, 甚至婴儿会试图回应他人的情感需求, 例如安慰哭泣 的人。 ${ }^{[16]}$ 同理心的存在表明孩子具有亲社会行为, 而亲社会行为是公平感存在的前提条件。 因此, 对儿童进行公平感测试是可行且有意义的。目前研究者选择的儿童被试年龄大部分在 18岁以下, 借此探究公平行为的发展过程。[17]

就国外研究来看, 随着年龄的增长, 作为提议者的未成年人会分给对手更多的钱, 或者 提出更公平的分配方案; 而作为回应者的未成年人也会更多的拒绝不公平分配。[18-19]早在1975 年, Damon ${ }^{[20]}$ 提出4岁的儿童在奖励分配的问题上就已具备公平观念。Harbaugh et al. ${ }^{[21]}$ 进行 了儿童的独裁者博弯实验 ${ }^{1}$, 结果表明提议者的分配方案随着年龄增长而趋向公平。同样在 Kogut ${ }^{[22]}$ 的实验中这一结论也得到了验证。该实验表明3到8岁的儿童选择公平分配的比例随着 年龄的增长而上升。其中5到8岁的儿童虽然已有公平概念, 但他们未对自己的选择在情感上 有所反馈; 而9到10岁的儿童在作出公平分配时表现出了对这一决策的满意, 即随着年龄增长 儿童展现出了不公平厌恶这一偏好。不公平厌恶对人类合作的演进起到了关键作用 ${ }^{[23]}$, 而由 儿童展现出的这样一种偏好证明了公平行为是儿童道德发展的重要内容。

尽管在奖励分配中儿童具有公平观念 ${ }^{[24]}$, 但是儿童的公平感是否与生俱来？ Castelli et al. ${ }^{[25]}$ 选择 8 至 10 岁的儿童进行最后通牒博弯实验, 结果发现作为提议者, 儿童在 8 至 10 岁已经 具备了公平准则的观念并且擅于利用这一准则——只有当发现信息不对称时才呈现一种自私 的偏好; 而作为响应者, 儿童展现出一种矛盾一一拒绝在公平的决策过程中产生的不公平份 额。研究者将这一结果解释为儿童对公平结果的渴望超过了对公平决策过程的信任。除了证 明儿童对结果公平具有考量外, 研究者也将重点放在儿童对公平的敏感性上。Wittig et al. ${ }^{[26]}$ 选择了五岁的儿童进行实验来研究学龄前儿童的公平敏感性的本质。结果表明只有当知道提 议者本可以作出“均等”决策却没有那样做之后, 响应者才有了拒绝的行为, 而提议者却对此 并不知情。因此研究者提出学龄前儿童通常将公平与“均等”划等号, 而“均等”的要求要远高 于公平。儿童对公平结果的强烈渴望和对公平标准的严格定义, 可以算作儿童天生具有公平 意识的证据之一。

\footnotetext{
1独裁者博弯 (Dictator Game, DG) 是最后通牒博弯的一个变体实验, 由Kahneman（1986）首次提出, 在该实 验中响应者被剥夺了选择接受或者拒绝的权利, 成为一个单纯的接受者（Recipient）。
} 
Camerer ${ }^{[4]}$ 提出礼仪在儿童实验中的作用更为重要。相关研究指出儿童公平行为可能来自 后天教育而非基因 ${ }^{[21]}$, 并将重点聚焦在孩子表现出利他行为的年龄阶段以及他们的家庭背景。 Benenson et al. ${ }^{[27]}$ 选择4岁、6岁和9岁的英国孩子进行独裁者博弯实验来研究利他行为, 发现 即便是年龄最小的孩子也展现出了利他行为, 而生活在更好的经济社会环境中的孩子与较差 经济社会环境中的孩子相比，他们表现出更加无私的品格。实验结果表明社会实践影响了儿 童的利他行为。Hoffmann \& Tee ${ }^{[17]}$ 将平均年龄为 12 岁的青少年与成人组成混合年龄进行实验, 发现青少年提议者, 尤其是来自亚洲的提议者给出公平方案的比例远超成年提议者, 青少年 响应者的拒绝率也低于成年响应者。研究者将这一年龄效应归因于文化, 认为亚洲青少年更 受到合作与和谐文化的熏陶。

总体上看，未成年儿童的公平感会随着年龄的增长而有所提升。这可能是由于受到教育 和道德等因素的影响, 使得儿童在成长过程中逐渐意识到合作的重要性, 进而表现出公平的 倾向。相关研究证明了人类的公平感是不断演化进步的这一结论。

\section{4. 基于不同社会环境的实验}

对公平感的研究发现，从原始社会、农业社会到工业社会，处于不同社会阶段的人对公 平的感知有着明显的差异，公平感也表现出随着社会环境的变化而不断进化的特点。

无论是身处工业社会或是非工业社会，不同国籍和种族的个体在决策时有着明显差异。

${ }^{[3]}$ Henrich et al. ${ }^{[28]}$ 横跨五大洲, 选取了诸如坦桑尼亚的哈扎部落、玻利维亚的提斯曼原住民等 15 个非工业社会进行了实验。实验结果表明来自巴布亚新几内亚的被试展现出了公平感, 其 中来自奥和格瑙的响应者拒绝了不公平和超公平的分出额, 来自阿乌的提议者则愿意分出一 半以上的奖金给对方。据对当地文化的研究, 研究者提出当地人对太过慷慨或太过吝啬的馈 赠通常都会拒绝。这一发现证实了人的行为并不总是纯粹的自私自利, 他们对于公平的理解 不仅有均等, 更有“多劳多得”这一认知。在中国, Chen \& Tang ${ }^{[29]}$ 针对宗教文化的影响程度对 藏族人与汉族人进行了最后通牒博峦实验。实验表明藏族人更愿意接受分出额并且他们的决 定与给定的禀赋大小无关。因为宗教信仰程度的不同，藏族人与汉族人的行为因为不同的文 化和价值观产生了明显差异。Oosterbeek et al. ${ }^{[30]}$ 将37份在不同文化下进行最后通牒博弯实验 的结果进行元分析，发现尽管被试的国籍种族不尽相同，但是提议者的平均分出额为 $40 \%$, 并且响应者拒绝 $16 \%$ 左右的分出额。这份对来自欧洲、亚洲和北美洲的元分析报告显示人类 具有稳健的公平感，世界各地的人大多很看重公平待遇。

在社会演进的过程中，工业社会个体的公平感要强于原始社会或农业社会。Henrich ${ }^{[31]}$ 在秘鲁对当地土著人进行实验, 并与来自加州大学的人类学研究生进行对比。实验发现来自 马其根加部落的被试与来自工业社会的人的行为呈现出巨大差异。前者的平均分出额是 $26 \%$ 并且较低的分出额几乎全被接受了; 而后者的平均分出额是 $48 \%$ 并且较低的分出额都被拒绝 了。研究者认为部落的提议者似乎不认为自己具有义务进行平均分配, 而响应者也并未期待 得到一个公平的份额。对于土著人来说, 分出 $15 \%$ 已经是一个公平的选择。相隔一年, Henrich et al. ${ }^{[28]}$ 基于原始部落的实验结果也与以往基于工业社会的实验结果截然不同。例如研究者指 出提斯曼原住民没有拒绝行为, 但分出额在 $50 \%$ 左右; 马奇根加部落居民有 1 次拒绝行为, 但 是 $75 \%$ 的分出额低于初始禀赋的 $30 \%$, 其平均 $26 \%$ 的分出额远低于西方工业社会的 $45 \%$ 。由此 可见工业社会个体的公平感更胜一筹。

市场化程度是社会演进过程中不可忽略的因素之一。相较于工业社会，农业社会或原始 社会的个体受市场影响程度较小，他们通常以家庭为活动单位进行生产、交换与分享。分享 是人类具有的利他行为之一, 尤其是在猎人这一群体中存在着大量的食物分享行为和强烈的 平等主义思想。 ${ }^{[32-33]}$ Marlowe $\mathrm{e}^{[34]}$ 选择了来自坦桑尼亚的猎人进行最后通牒博弯和独裁者博弯 实验。尽管猎人文化强调分享与公平, 并且提议者有公平甚至超公平的分配方案, 但其平均 分出额远低于工业社会的提议者。同样在Henrich et al. ${ }^{[28]}$ 的实验中，研究者也提出市场一体化 程度对公平观念有着巨大的影响, 因为实验表明在一个习惯与熟人进行交易的社会中, 个体 
对陌生人展现利他行为的动机也微乎其微。而在一个依赖市场的社会中则呈现出不同的结果。 1991年, Roth et al. ${ }^{[35]}$ 首次将文化作为影响人类决策的因素与最后通牒博弯相结合进行研究, 在以色列, 日本，美国和南斯拉夫这四个工业化国家进行实验。实验结果显示各国提议者的 分出额都接近 $50 \%$ ，其中日本提议者达到 $60 \%$; 而以色列人相较美国人更容易接受提议者的 分出额。研究者将各国实验者行为的差异归因于文化。尽管Marlowe $\mathrm{e}^{[34]}$ 的实验没有证明猎人 有异常的公平感，但将不同社会形态下的个体进行对比，对于论证公平感的演变是有意义的。

通过上述一系列关于社会环境的实验，不难发现非工业社会的实验者无论是分配金额或 是拒绝率都要显著低于工业社会。农业社会或原始社会的个体的表现更加“自利”，这暗示着 在进入工业文明后，人类的经济行为才开始偏离“理性人”假设。[36]

\section{5. 基于大脑神经基础的实验}

近年来, 随着脑成像技术的日趋成熟, 研究者将事件相关电位(event-related potential, ERP) 、功能性磁共振成像(functional magnetic resonance imaging, fMRI)等技术应用于最后通 牒博峦实验中, 来探测人类做出公平决策时活跃的脑区。经典的研究方法与神经影像学的结 合使研究者可以从神经角度对个体公平感问题有更本质的探索。

在最后通牒博弯中，提议者和响应者关于公平的神经基础各不相同。对于响应者, Sanfey et al. ${ }^{[37]}$ 使用fMRI进行最后通牒博恋实验。研究发现面对不公平提议时, 响应者的双侧前脑岛、 背外侧前额叶皮层和前扣带皮层激活明显增强。其中与公平准则最密切的脑区是前脑岛和背 外侧前额叶皮层，分别与被试的情绪和认知有关。前者一般被认为反映了个体面对不公平待 遇时的负面情绪, 激活程度较高时, 被试拒绝不公平提议一一即拒绝不公平提议时, 前脑岛 的高度活跃显示了在决策时情绪的重要作用; 而后者主要负责决策过程中的控制, 激活程度 较高时, 则作出对不公平提议的接受决策。而决策时情绪和认知产生的矛盾则激活了前扣带 皮层。对于提议者, Weiland et al. ${ }^{[38]}$ 的研究结果表明, 实验中提议者提出公平分配方案时,

其题上回、颢极、内侧前额叶皮层、内侧眀额皮层及纹状体等涉及心理理论与奖赏的核心脑 区的激活程度显著强于提出不公平分配方案时。这样一个跨学科的研究使得对公平的神经基 础有了更深入的理解。

近年来研究者将最后通牒博弯应用于研究临床病例, 对病人这一群体的公平感及其神经 基础进行探索, 研究病患决策的特点, 以改善个体的日常决策、合作及生活等方面。认知能 力影响着决策和战略思维, 而认知功能障碍被认为是精神分裂症的一个基本特征 ${ }^{[39]}$, 并且精 神分裂者在决策时被认为大脑中的脑岛和背外侧前额叶皮层是受损害的。Agay et al. ${ }^{[40]}$ 选择了 患有精神分裂症状的被试进行了最后通牒博峦实验, 并与健康组进行对照。实验前研究者推 测认知障碍和判断障碍会损害病人的讨价还价能力。实验结果发现作为提议者的病人并不能 完全利用自己的决策能力, 他们对公平、不公平和过度公平有着错误的判断。作为提议者, 病人组作出的超公平份额与健康组的公平份额一样多; 而对于分出不公平份额, 病人组远少 于健康组。作为响应者, 病人与健康组相差无几, 而这也是研究者认为应该要进一步研究的 问题。实验的意义在于未来更好的评估患者的决策能力, 继而开发新的治疗策略, 使他们自 己能够维持日常生活。Vieira et al. ${ }^{[41]}$ 对精神病态者的决策行为进行了研究。研究发现精神病 态低分组被试对不公平方案的接受率与背外侧前额叶皮层的激活呈正相关, 而高分组的接受 率则与腹内侧前额叶皮层的激活存在负相关。这意味着患病程度不同, 被试决策行为也有着 不同的神经基础。因此继续探索精神病态患者适应良好及适应不良社会决策的神经基础是极 其重要的。[42]

\section{6. 结语}

在这个不公平的世界里, 短视的利已主义终会被公平所取代, 这是公平的进化。[43]通过 以上对最后通牒博峦实验及其变体、被试个体差别和对未来研究方向的分析, 我们可以看到 
人类的公平感是进化的。其中灵长类动物也表现出某种程度上的公平行为, 但目前研究尚未 证实这种行为是稳健的。关于选择动物作为实验被试进行人类公平感的进化论证应集中于实 验过程的设计与控制, 例如未来的研究可以增加 “盗窃” 或更积极的拒绝方式等手段, 以更 好地利用愤怒的作用来研究动物中是否存在不公平厌恶。关于儿童的最后通牒博弯实验显示 儿童的公平感随着年龄增长而上升, 这一结论得到了大量实验数据的支持。在世界各地的成 人实验中, 人类更加展现出人性中信任、合作、公平、互惠甚至利他的一面, 这与社会人所 接受的教育、所生存的环境与所积累的人生经验不无关系。虽然各地文化不尽相同，但是大 量结果显示人类具有公平感, 因此与信任博弯、公共物品博弯和囚徒困境等其他博弯实验相 比, 最后通牒博弯因其稳健的结果从根本上质疑了 “理性经济人” 假设。[44]当然, 这些实验 的目的不在于推翻传统经济学的观点。走出实验室之后, 如何将实验结果付诸实践, 提高人 类的合作水平, 改善个体的生活质量, 更好的为现实生活服务, 将是未来研究者思考的方向。

\section{致谢}

本文为国家社科基金青年项目《社会公平的微观基础研究》(12CJL007)的阶段性成果之

\section{References}

[1] Zhang Shuwei, Social justice, institutional trust and public cooperation intention, Acta Psychologica Sinica, Vol.49, pp.794-813, 2017.

[2] W. Güth, R. Schmittberger, and B. Schwarze, An experimental analysis of ultimatum bargaining, Journal of Economic Behavior \& Organization, Vol.3, pp.367-388, 1982.

[3] C. Camerer and F. Colin, Behavioral game theory: Experiments in strategic interaction, Cuadernos de Economía, Vol.23, pp.229-236, 2004.

[4] C. Camerer and R.H. Thaler, Anomalies: Ultimatums, Dictators and Manners, The Journal of Economic Perspectives, Vol.9, pp.209-219, 1995.

[5] F. Warneken and M. Tomasello, Altruistic helping in human infants and young chimpanzees, Science (New York, N.Y.), Vol.311, pp.1301-1303, 2006.

[6] S.F. Brosnan and F.B. De Waal, Monkeys reject unequal pay, Nature, Vol.425, pp.297-299, 2003.

[7] J.C. Mitani, D.A. Merriwether, and C. Zhang, Male affiliation, cooperation and kinship in wild chimpanzees, Animal Behaviour, Vol.59, pp.885-893, 2000.

[8] J.C. Mitani and D.P. Watts, Why do chimpanzees hunt and share meat, Animal Behaviour, Vol.61, pp.915-924, 2001.

[9] S.F. Brosnan, H.C. Schiff, and F.B. De Waal, Tolerance for inequity may increase with social closeness in chimpanzees, Proc Biol Sci, Vol.272, pp.253-258, 2005.

[10]D. Proctor, R.A. Williamson, F.B.de Waal, et al, Chimpanzees play the ultimatum game, Proceedings of the National Academy of Sciences of the United States of America, Vol.110, pp.2070, 2013.

[11]Massen, J.M. Jorg, et al, Generous Leaders and Selfish Underdogs: Pro-Sociality in Despotic Macaques, Plos One, Vol.5, e9734, 2010.

[12]J. Bräuer, J. Call, and M. Tomasello, Are apes really inequity averse, Proceedings: Biological Sciences, Vol.273, pp.3123-3128, 2006. 
[13]J. Bräuer, J. Call, and M. Tomasello, Are Apes Inequity Averse? New Data on the Token-Exchange Paradigm, American journal of primatology, Vol.71, pp.175-181, 2009.

[14]K. Jensen, J. Call, and M. Tomasello, Chimpanzees are rational maximizers in an ultimatum game, Science, Vol.318, pp.107-109, 2007.

[15]I.Kaiser, K. Jensen, J. Call, et al, Theft in an ultimatum game: chimpanzees and bonobos are insensitive to unfairness, Biology Letters, Vol.8, pp.942, 2012.

[16]L.A. Vogt, Empathy and Moral Development: Implications for caring and Justice, The Canadian child and adolescent psychiatry review, Vol.12, pp.46, 2003.

[17]R. Hoffmann and J.Y. Tee, Adolescent-adult interactions and culture in the ultimatum game, Journal of Economic Psychology, Vol.27, pp.98-116, 2003.

[18]W.T. Harbaugh and K. Krause, Children's altruism in public good and dictator experiment, Economic Inquiry, Vol.38, pp.95-109, 2000.

[19]N. Steinbeis, B.C. Bernhardt, and T. Singer, Impulse Control and Underlying Functions of the Left DLPFC Mediate Age-Related and Age-Independent Individual Differences in Strategic Social Behavior, Neuron, Vol.73, pp.1040, 2012.

[20]W. Damon, Early Conceptions of Positive Justice as Related to the Development of Logical Operations, Child Development, Vol.46, pp.301-312, 1975.

[21]Harbaugh, T. William, K. Krause, and S.J. Liday, Bargaining by Children, University of Oregon Economics Department Working Papers, Vol.12, pp.547-569, 2003.

[22]T. Kogut, Knowing what I should, doing what I want: From selfishness to inequity aversion in young children's sharing behavior, Journal of Economic Psychology, Vol.33, pp.226-236, 2012.

[23]E. Fehr and U. Fischbacher, Human Altruism - Proximate Patterns and Evolutionary Origins, Analyse \& Kritik, Vol.27, pp.6-47, 2005.

[24]K.R. Olson and E.S. Spelke, Foundations of Cooperation in Young Children, Cognition, Vol.108, pp.222-231, 2008.

[25]I.Castelli, et al, Fairness norms and theory of mind in an ultimatum game: judgments, offers, and decisions in school-aged children, PLOS ONE, Vol.9, e105024, 2014.

[26]M.Wittig, K. Jensen, and M. Tomasello, Five-year-olds understand fair as equal in a mini-ultimatum game, Journal of Experimental Child Psychology, Vol.116, pp.324, 2013.

[27]J.F. Benenson, J. Pascoe, and N. Radmore, Children's altruistic behavior in the dictator game, Evolution and Human Behavior, Vol.28, pp.168-175, 2007.

[28]J. Henrich, et al, Economic man in cross-cultural perspective: Behavioral experiments in 15 small-scale societies, Behaviorals\&brain Sciences, Vol.28, pp.815-55, 2005.

[29]Chen, Kang, and F.F. Tang, Cultural differences between Tibetans and ethnic Han Chinese in ultimatum bargaining experiments, European Journal of Political Economy, Vol.25, pp.78-84, 2009.

[30]H. Oosterbeek, R. Sloof, and G.V.D.Kuilen, Cultural Differences in Ultimatum Game Experiments: Evidence from a Meta-Analysis, Experimental, Vol.7, pp.171-188, 2004.

[31]J. Henrich, Does Culture Matter in Economic Behavior? Ultimatum Game Bargaining among the Machiguenga of the Peruvian Amazon, The American Economic Review, Vol.90, pp.973-979, 2000. 
[32] W.C. Mcgrew and A.T.C. Feistner, Two nonhuman primate models for the evolution of human food sharing: chimpanzees and callitrichids, The Adapted Mind. Evolutionary Psychology and the Generation of Culture, Vol.4, pp.229-243, 1995.

[33]C.Boehm, Hierarchy in the forest: the evolution of egalitarian behavior. Harvard University Press, 1999.

[34]F. Marlowe, Dictators and ultimatums in an egalitarian society of hunter-gatherers, the Hadza of Tanzania, Framed Field Experiments, Vol.262, pp.95-103, 2004.

[35]A.E. Roth, Prasnikar V, Masahiro Okuno-Fujiwara, et al, Bargaining and Market Behavior in Jerusalem, Ljubljana, Pittsburgh and Tokyo: An Experimental Study, Levine's Working Paper Archive, Vol.81, pp.1068-1095, 1998.

[36] $\mathrm{Li} \mathrm{Ou}$, et al, The individual and cultural difference in the ultimatum game, Journal of Psychological Science, Vol.3, pp.693-699, 2016.

[37]A.G. Sanfey, J.K. Rilling, J.A. Aronson, et al, The Neural Basis of Economic Decision-Making in the Ultimatum Game, Science: New York, Vol.300, pp.1755, 2003.

[38]S. Weiland, J. Hewig, H. Hecht, et al, Neural correlates of fair behavior in interpersonal bargaining, Social Neuroscience, Vol.7, pp.537-551, 2012.

[39]T. Sharma and L. Antonova, Cognitive function in schizophrenia, Deficits, functional consequences, and future treatment, Psychiatric Clinics of North America, Vol.26, pp.25-40, 2003.

[40]N. Agay, S. Kron, Z. Carmel, et al, Ultimatum bargaining behavior of people affected by schizophrenia, Psychiatry Research, Vol.157, pp.39-46, 2008.

[41]J.B. Vieira, P.R. Almeida, F. Ferreirasantos, et al, Distinct neural activation patterns underlie economic decisions in high and low psychopathy scorers, Soc Cogn Affect Neurosci, Vol.9, pp.1099-1107, 2014.

[42] Wang Yun, et al, Neural basis of fairness, Science \& Technology Review, Vol.33, pp.83-92, 2015.

[43]D.G. Rand, C.E. Tarnita, H. Ohtsuki, et al, Evolution of fairness in the one-shot anonymous Ultimatum Game, Proceedings of the National Academy of Sciences of the United States of America, Vol.110, pp.2581-2586, 2013.

[44]W. Güth and M.G. Kocher, More than thirty years of ultimatum bargaining experiments: Motives, variations, and a survey of the recent literature, Journal of Economic Behavior \& Organization, Vol.108, pp.396-409, 2014. 